\title{
Dictogloss Approach to Dictation Writing Activities
}

Siranoush Ghaltakhchyan

Yerevan State University

\begin{abstract}
The present article is devoted to the study of modern approaches to dictation writing activities, namely to dictogloss approach, the purport of which is, first and foremost, to build a solid foundation of the English language proficiency and enhance integrated language skills in context. As different from traditional dictation writing activities, that aim at helping language learners become accustomed to processing and differentiating between different sounds of the target language, identifying words and phrases and recording them as accurately as possible, the dictogloss method of dictation writing tries to boost listening for detailed understanding, i.e. focusing on the grammatical constructions used in the texts, guessing the words and phrases suitable to the context, constructing meaning from the recorded texts and interpreting the gist of the dictated stories. Our study shows that the effectiveness of dictation writing activities in EFL classroom increases and the dictogloss procedure becomes more enjoyable and challenging in case of the intensive use of authentic materials, i.e. when the texts are not dictated directly by the teachers themselves, but are told by native speakers recorded on CDs.
\end{abstract}

Key words: methods of EFL teaching, language learning activities, interactive learning, cooperative and collaborative learning, dictation writing activities, dictogloss approach, dictogloss prosedure, audio dictation.

\section{Introduction}

In its simplest and traditional form dictation writing refers to the teacher reading some text aloud in the language classroom so that the language learners can write down what is being dictated by the teacher, word for word, phrase by phrase, later the teacher checking their written works against the original text, and correcting the errors made. According to this approach, dictation is perceived as a one-way activity which is mainly intended to develop students' phonological awareness and spelling skills (Manzo 1990; Davis, Rinvolucri 2002; Saraswathi 2004; Alkhuli 2006). 
Apart from this strictly controlled listen-and-spell approach, there are a number of different creative ways of conducting dictation writing activities to incorporate dictation in the daily practice of language skills, to help teachers develop effective learning strategies for improving integrated language skills, making dictation writing more interesting, motivating, learner-centred and student-oriented. Thus dictation writing can be conducted in combination with a range of challenging activities to provide an opportunity for the language learners to study English with more comprehension and ease, to make the learning process more efficient and enjoyable.

\section{Dictation Writing}

Dictation is one of the oldest techniques used to test progress in the process of foreign language learning. It can actually be an effective language-teaching technique and an efficient language-learning activity. Dictation writing is one of the few activities in the EFL classroom that can be applicable with both small and large groups of language learners. It provides a reasonable chance for the teacher to engage the whole group in the process of language acquisition and enables the learners to become focused on the task throughout the activity.

While speaking about the merits of dictation writing activities, P. Davis and M. Rinvolucri state that "dictation is ideal for occupying the conscious mind while stimulating the unconscious into action" (Davis, Rinvolucri 2002:6). Moreover, J. Grinder and R. Bandler note that in dictation, apart from the implicit control of topic and activity, there is often a semi-hypnotic aspect to the exercise that calms the language learners down and puts all of them, as well as the teacher, into a slight trance (Grinder, Bandler 1981).

Nevertheless, the effectiveness of dictation writing activities is to a great extent dependent upon the fact how it is handled, i.e. what techniques and approaches are employed to reach the specific goals and achieve good learning outcomes in the process of dictation writing.

\section{Collaborative and Cooperative Learning}

It is common knowledge that nowadays great importance is attached to the implementation of communicative language teaching and cooperative/collaborative learning activities in the EFL classroom. It requires from each language learner in the group to develop a sense of personal responsibility to learn and help the rest of the group to learn too, it promotes learners to work together in groups to support 
each other to maximize their own learning and improve that of the others (Jollife 2007; Celce-Murcia 2001).

So, in order to become cooperative, language learners must do teamwork to accomplish shared goals. Each member of the team should feel responsible for and accountable to the other members, bearing in mind that each member brings strength, unity and contribution to the group. Any member who appears to be noncooperative and non-participating should be encouraged by the same group and promoted to develop a sense of togetherness and an ability of giving and receiving personal feedback.

Studies have shown that as a result of cooperative learning, language learners obtain greater productivity and problem-solving ability in the language learning process, they develop better interpersonal relationships and unfold a sense of belonging and mutual support. Their psychological health and social competence is improved and they acquire higher self-esteem and increased self-confidence (McCafferty et al. 2006; Jollife 2007).

\section{Dictogloss Prosedure}

These relatively recent trends in EFL teaching methods have encouraged a relatively new approach to dictation writing. It is the so-called dictogloss approach, which is a more interactive and cooperative method to language acquisition and language proficiency. Dictogloss is a classroom dictation writing activity in which the language learners are asked to note down key words and phrases or chunks of ideas and even sentences in a jumbled order, while listening to the dictated text. To facilitate the development of collaborative and communicative learning skills and to allow the students to learn from each other, the students may be asked to work in pairs or in small groups to reconstruct the text from their shared resources. Afterwards, the final versions are compared, discussed and analyzed (Wajnryb 1990; Kowal, Swain 1997; Davis, Rinvolucri 2002; Richards, Schmidt 2009; Jeremy 2012).

The language learners are supposed not to replicate the original text but rather to produce a piece of writing that closely reflects the sense of the original, and that involves similar structures used in the original. As R. Wajnryb states, essentially it consists of asking learners to reconstruct a dictated text so as to capture as much as possible of its information content in as accurate and acceptable a linguistic form as possible. It is a teaching procedure the aim of which is, first and foremost, to improve the students' understanding and use of grammar (Wajnryb 1990). 
It is worth mentioning that like other language learning activities, dictation should be contextualized to illustrate the communicative use of the target language and enable the language learners to process information, make connections and progress toward the successful end in language proficiency. Dictogloss approach to dictation writing comes to meet these needs and support language learning process. In the dictogloss procedure language learners may pay attention to things they did not come to know, they begin to notice and even correct their own mistakes connected with not only spelling, but also the right word choice, word collocations, the relationships between words and their grammatical structures (Doughly, Williams 1998). This kind of activity will contribute greatly to the language acquisition and, as R. Wajnryb suggests, "through active learner involvement students come to confront their own strengths and weaknesses. ... In so doing, they find out what they need to know" (Wajnryb 1990:10).

In the reconstructing process, special emphasis should be placed on the vocabulary, grammatical accuracy of the sentences, the connection between ideas supported by appropriate cohesive devices, etc. This activity provides an opportunity for the language learners to be more aware of the sequence of events and the logical organization of texts. In this connection C. Doughly and J. Williams mention that in the reconstruction process the teacher should provide the language learners with "a demonstration of rules in action, in a very specific linguistic context" (Doughly, Williams 1998:74). To do this, the teacher should draw attention to the grammatical forms, provide an explanation for them and support the language learners to find possible ways to solve the encountered linguistic problems.

Dictogloss procedure can lead to oral communicative activities among the language learners. After reconstructing their own version of the dictated text, the students are asked to read them aloud, analyse the used words, phrases and the grammatical constructions, compare their written works with the original text as well as with their peers' works, work in small groups and discuss the results and share opinions about them. They may even add a new paragraph at the end of their version of the dictated text, and introduce their own opinion in written form or orally. Thus, as P. Davis, M. Rinvolucri note “'the inside self' thinking that has taken place during the dictation phase leads naturally into comparing experiences with other members of the group" (Davis, Rinvolucri 2002:5).

Dictogloss approach to dictation writing also becomes a useful tool to develop language learners' note-taking skills, which is an important language development 
strategy that facilitates the language learners' ability to focus attention on key information, to search for key words and phrases, to distinguish between important and unnecessary information, and record the main ideas. In this stage of writing, the language learners should not worry about the order of ideas, the sequence of tenses, spelling of the words, etc. They should just keep on writing down whatever their ear grasps or whatever they consider essential and worth writing. These notes are supposed to guide them throughout the writing process and help them be clear, concise and to the point in the process of reconstructing the texts.

Dictogloss procedure is particularly useful in helping students rely on their memory and apply their vocabulary and grammar knowledge in writing. In this connection R. Wajnryb states that during the dictogloss procedure, because of the speed of the reading and the density of the text, the language learners manage to produce a fragmented text where the essential cohesion is missing. As a result there exists an "information gap" which should be filled in the reconstructing process by relying on the memory as well as the creativity of the language learner (Wajnryb 1990).

\section{Assessment of Dictogloss Dictations}

It is common knowledge that dictation is an efficient and useful device to help the EFL language teachers to understand and assess the students' learning progress. It is the teachers' duty not only to identify and correct the language learners' mistakes, but also to provide them with constructive feedback by commenting on their mistakes, analyzing certain comprehension and production problems and giving suggestions for improvement.

Nevertheless, dictation writing can also be conducted to motivate learners and promote autonomy in language learning. In the dictogloss procedure the teachers may move beyond assessing the language learners' spelling and listening skills, and develop their reading skills as well if they allow the language learners to review their own written works. Dictation writing activities where the language learners compare their version of the text to the original one can increase their critical awareness (Wajnryb 1990; Kowal, Swain 1997, Davis, Rinvolucri 2005). They may notice aspects of the language that are sometimes overlooked, they may manage to find some common mistakes, such as spelling errors, absence of articles, the third person singular $s$, misunderstood words, incorrect tense forms etc.

Sometimes, however, the language learners may fail to notice some mistakes in their own written works when comparing it to the original text. Thus, the EFL 
teachers should often ask language learners to exchange the written works with their peers, giving them a chance to check and point out the errors made by their class-mates. The exchange of written works may be a good opportunity for language learners to identify their own errors better.

\section{The Dictogloss Procedure and Audio Dictations}

As we know, it is always advisable for the language teachers that they make necessary adaptations to match the needs and abilities of the language learners in the EFL classroom. In our opinion, it may concern also the dictogloss techniques the teacher employs in the EFL classroom that will increase or decrease the complexity of the dictation writing activity.

It is worth mentioning, that we have successfully been employing the dictogloss procedure in the EFL classroom at Yerevan State University in the Department of English for Cross-Cultural Communication for a couple of years. During these years we came to understand that EFL students like the dictogloss procedure, since it enables them to feel free to demonstrate their knowledge and to be actively engaged in the process of the English language acquisition.

Nevertheless, in the recent years we tried to approach the dictogloss dictation writing procedure in a slightly different way, having in mind to attach a new application to the procedure. We started to work with the first-year students, especially with the groups of students possessing a good command of the English language, and employed the dictogloss procedure in combination with the technique of using authentic material, namely the audio recordings of the texts told by native speakers.

The main purport of the novel approach to dictogloss dictation writing activities is to facilitate the development of EFL students' listening comprehension as well as to improve their writing skills in the process of dictation writing. Furthermore, we aim at developing a range of sub-skills starting from letter formation, spelling, punctuation, etc. So, our studies have shown that the dictogloss procedure in combination with audio dictations provides opportunities for the students to upgrade practice in almost every aspect of foreign language learning, including vocabulary, grammar and syntax and to develop practice in understanding spoken English. Thus, the final goal of implementing the dictogloss procedure in EFL classroom is to provide the necessary input that facilitates the English language acquisition. 
The dictogloss procedure includes several steps or phases. At first, the students are asked to listen to the recorded text and grasp its overall meaning. Then, in order to improve the students' command of vocabulary and grammar, the teacher brainstorms the key words and supporting details with them and focuses their attention on the new words and phrases. She asks them to identify, spell and define, sometimes even to translate certain words or phrases, to paraphrase sentences or clauses that are somehow difficult to comprehend, to discuss some grammatical structures used in the texts and identify their correct and appropriate usage, etc.

For additional reinforcement, the recording may be replayed for two or more times, depending on the difficulty of the text and the language level of the students. Afterwards, the students work together in a group, trying to reconstruct the text according to their shared notes, as it is usually done in the dictogloss procedure described above.

In this procedure it is possible to enhance individual reading skills, too. For this purpose, the teacher asks each student in the group to read a section of his/her version of the text to the rest of the group. This kind of activity encourages the students to listen to each other, to compare their pronunciation and intonation with the original, and to highlight the importance of clear and correct pronunciation.

Hence, we may state that the use of audio dictation technique in the dictogloss procedure promotes renewal and rebirth of the traditional practice of dictation writing, bringing it on the up-to-date level of language acquisition. With the help of this technique, the dictogloss dictation writing becomes an extremely versatile activity which can facilitate development of the four basic language skills: listening, writing, reading and speaking. It enables the students to build a solid foundation of the English language proficiency and incorporate integrated language skills to the best advantage and, what is not less important, to make the process more enjoyable, motivating and challenging.

\section{Conclusion}

To sum up, it should be stated that dictation writing is a very useful and flexible activity, which can be made also enjoyable if new and motivating approaches are introduced to it. The dictogloss approach to dictation writing gives the opportunity for the language learners to enhance a number of essential language skills. It helps them to improve their spelling ability, provides training in employing appropriate 
punctuation marks. It directs the language learners' attention to new grammatical constructions, enlarges their vocabulary and enhances the practice of using them in the correct context. It also strengthens the ability to memorize phrases, clauses and sentences and to record them appropriately. It gives the language learners much practice in concentrated listening and understanding skills.

The dictation writing process becomes more entertaining and challenging when audio recordings of the texts are employed in the dictogloss procedure. It presupposes language learners' active engagement in the activity, and strives to facilitate students' basic language skills, involving listening, writing, reading as well as speaking. Hence, dictogloss approach to dictation writing with the help of audio recordings is an enjoyable, efficient and motivating way to incorporate integrated language skills to the best advantage.

\section{References:}

1. Alkhuli, A.M. (2006) Methods of Teaching English. Jordan: Dar Alfalah.

2. Celce-Murcia, M. (2001) Teaching English as a Second or Foreign Language. $3^{\text {rd }}$ edition. USA: Thomson Learning, Inc.

3. Davis, P.; Rinvolucri, M. (2002) Dictation, New Methods, New Possibilities. Cambridge: CUP.

4. Doughty, C.; Williams, J. (1998) Focus on Form in Classroom Second Language Acquisition. Cambridge: CUP.

5. Grinder, J.; Bandler, R. (1981) Trance-Formation: Neuro-Linguistic Programming and the Structure of Hypnosis. Moab, Utah: Real People Press.

6. Graham S.; Perin D. (2007) A Meta-Analysis of Writing Instruction for Adolescent Students. // Journal of Educational Psychology. Vol. 99, No. 3. New York. Available at: $<$ http://citeseerx.ist.psu.edu/viewdoc/download?doi=10.1.1. 462.2356\&rep=rep1\&type $=$ pdf $>$ [Accessed August 2016].

7. Harmer, J. (2012) Essential Teacher Knowledge. Harlow: Pearson Education Limited.

8. Jolliffe, W. (2007) Cooperative Learning in the Classroom: Putting it into Practice. London: Paul Chapman Publishing.

9. Kowal, M.; Swain, M. (1997) From Semantic to Syntactic Processing: How Can We Promote it in the Immersion Classroom? / Ed. by Johnson R.; Swain M. New York: CUP. 
10. Kidd, R. (1992) Teaching ESL Grammar through Dictation. // TESL Canada Journal. Vol. 10, No. 1. Available at: <http://files.eric.ed.gov/fulltext/ EJ457629.pdf $>$ [Accessed June 2016].

11. Levi, C.M.; Ransdell, S. (2009) The Science of Writing: Theories, Methods, Individual Differences, and Applications. New York: Routledge.

12. Manzo, A.V.; Manzo, U.C. (1990) Content Area Reading: A Heuristic Approach. USA: Merrill Publishing Company.

13. McCafferty, S.G.; Jacobs, G.M; DaSilva Iddings, A.Ch. (2006) Cooperative Learning and Second Language Teaching. / Ed by J.C. Richards. Cambridge: CUP.

14. Richards, J.C.; Schmidt, R. (2009) Dictogloss, Longman Dictionary of Language Teaching and Applied Linguistics. New York.

15. Saraswathi, V. (2004) English Language Teaching: Principles and Practice. India: Orient Longman.

16. Second and Foreign Language Teaching Methods. // Enhancing Academic Achievement of Bilingual Learners. Available at: $<$ http://moramodules.com/ ALMMethods.htm $>$ [Accessed August 2016].

17. Tang, Q. (2012) The Effectiveness of Dictation Method in College English Vocabulary Teaching. // Theory and Practice in Language Studies. Vol. 2, N 7. Academy Publisher. Available at: <http://www.academypublication. com/issues/past/tpls/vo102/07/19.pdf $>$ [Accessed October 2016].

18. Wajnryb, R. (1990) Resource Book for Teachers: Grammar Dictation. / Ed by A. Maley. Oxford: OUP.

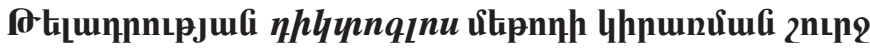

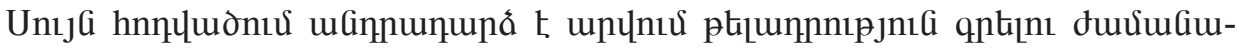

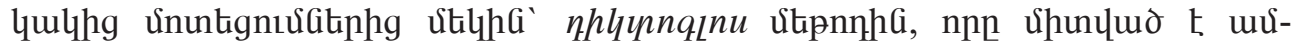

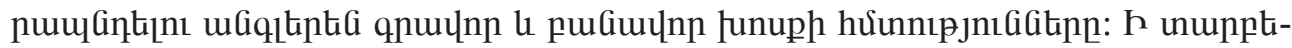

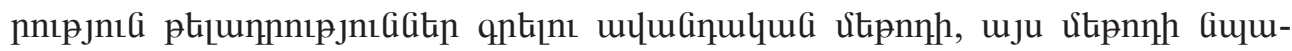

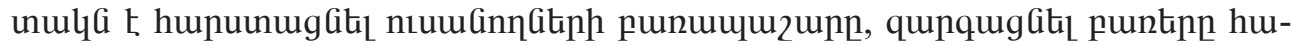

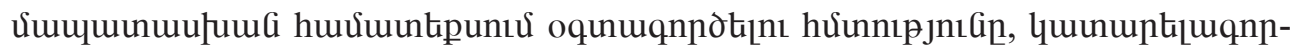

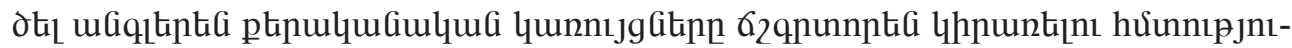

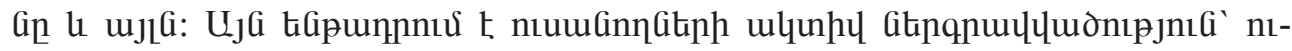

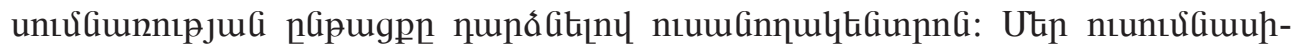

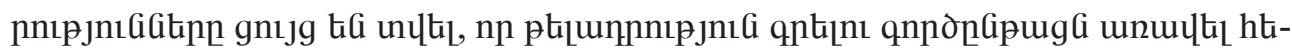




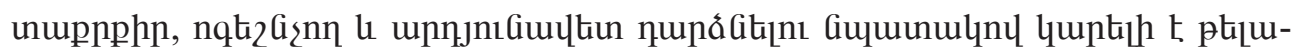

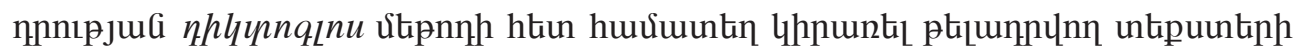

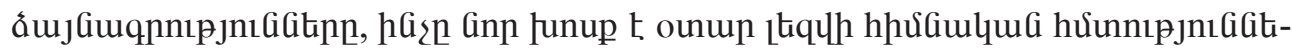

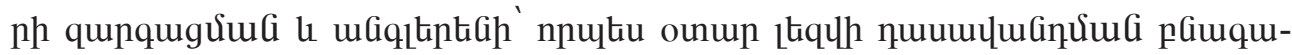
ไunntu: 